\title{
Bio-efficacy of different insecticides against leaf hopper, Empoasca kerri Pruthi (Cicadellidae: Hemiptera) in clusterbean
}

Ram Kishor Meena ${ }^{1 *}$, Ravindra Kumar Meena ${ }^{2}$, Uadal Singh ${ }^{1}$ and Manohari Lal Meena ${ }^{1}$

${ }^{1}$ College of Agriculture (SKNAU), Lalsot, Dausa (Rajasthan) India

${ }^{2}$ Department of Plant Breeding and Genetics, Sardarkrushinagar Dantiwada Agricultural University, Dantiwada (Gujarat) India

\section{ARITCLE INFO}

Received : 21.01 .2020

Revised : 11.02 .2020

Accepted : 26.02 .2020

\section{KEY WORDS :}

Acetamaprid, Imidacloprid, Thiamethoxam, Leaf hopper, Clusterbean
*Corresponding author:

Email : rkmeena.ento@sknau.ac.in

\begin{abstract}
Experiments were conducted during three cosecutive Kharif seasons (2015-17) to study the effect of commercially available insecticides formulations i.e. Acetamaprid $20 \%$ SP ( $0.4 \mathrm{~g} /$ litre of water), Imidacloprid $17.8 \% \mathrm{SL}(0.33 \mathrm{ml} /$ lit.), Quinalphos $\% 25 \mathrm{EC}(2.0 \mathrm{ml} /$ lit.), Thiamethoxam $25 \%$ WG (0.5 g/ lit.), Neem (Azadirachta indica) oil 2\% (20 ml/lit.), Karanj (Pongamia pinnata) oil 2\% (20 ml/lit.) against the Jassids, Empoasca kerri Pruthi in Clusterbean. The order of most effective insecticide was: Imidacloprid > Thiamethoxam> Acetamaprid. The maximum population reduction over control after 7 days of second spray was 71.76 and 70.14 per cent due to Imidacloprid, and Thiamethoxam during 2015. The same trend was found in 2016 and 2017. Thus, Imidacloprid was found most effective against the Jassids, Empoasca kerri Pruthi (Cicadellidae: Hemiptera).
\end{abstract}

How to view point the article : Meena, Ram Kishor, Meena, Ravindra Kumar, Singh, Uadal and Meena, Manohari Lal (2020). Bio-efficacy of different insecticides against leaf hopper, Empoasca kerri Pruthi (Cicadellidae: Hemiptera) in clusterbean. Internat. J. Plant Protec., 13(1) : 24-29, DOI : 10.15740/HAS/IJPP/13.1/24-29, Copyright@ 2020: Hind Agri-Horticultural Society. 